Article

\title{
Cloning, Expression, and Characterization of a New PL25 Family Ulvan Lyase from Marine Bacterium Alteromonas sp. A321
}

\author{
Jian Gao, Chunying Du, Yongzhou Chi, Siqi Zuo, Han Ye and Peng Wang * \\ College of Food Science and Engineering, Ocean University of China, Qingdao 266003, China \\ * Correspondence: pengwang@ouc.edu.cn; Tel.: +86-0532-82032290
}

Received: 25 August 2019; Accepted: 1 October 2019; Published: 8 October 2019

\begin{abstract}
Ulvan lyases can degrade ulvan to oligosaccharides with potent biological activity. A new ulvan lyase gene, ALT3695, was identified in Alteromonas sp. A321. Soluble expression of ALT3695 was achieved in Escherichia coli BL21 (DE3). The 1314-bp gene encoded a protein with 437 amino acid residues. The amino acid sequence of ALT3695 exhibited low sequence identity with polysaccharide lyase family 25 (PL25) ulvan lyases from Pseudoalteromonas sp. PLSV (64.14\% identity), Alteromonas sp. LOR (62.68\% identity), and Nonlabens ulvanivorans PLR (57.37\% identity). Recombinant ALT3695 was purified and the apparent molecular weight was about $53 \mathrm{kDa}$, which is different from that of other polysaccharide-degrading enzymes identified in Alteromonas sp. A321. ALT3695 exhibited maximal activity in $50 \mathrm{mM}$ Tris- $\mathrm{HCl}$ buffer at $\mathrm{pH} 8.0$ and $50{ }^{\circ} \mathrm{C}$. ALT3695 was relatively thermostable, as $90 \%$ activity was observed after incubation at $40{ }^{\circ} \mathrm{C}$ for $3 \mathrm{~h}$. The $K_{m}$ and $V_{\max }$ values of ALT3695 towards ulvan were $0.43 \mathrm{mg} \cdot \mathrm{mL}^{-1}$ and $0.11 \mu \mathrm{mol} \cdot \mathrm{min}^{-1} \cdot \mathrm{mL}^{-1}$, respectively. ESI-MS analysis showed that enzymatic products were mainly disaccharides and tetrasaccharides. This study reports a new PL25 family ulvan lyase, ALT3695, with properties that suggest its great potential for the preparation of ulvan oligosaccharides.
\end{abstract}

Keywords: ulvan-derived oligosaccharides; ulvan lyase; heterologous expression; polysaccharide lyase family 25

\section{Introduction}

Ulvan is a type of cell wall polysaccharide, extracted from marine green seaweed (genus Ulva and Enteromorpha) [1]. It is mainly composed of iduronic acid (IdoA), 3-sulfated rhamnose (Rha3S), xylose (Xyl), and glucuronic acid (GlcA) [1]. The repetitive disaccharide units in ulvan are Rha3S-GlcA, Rha3S-IdoA, and Rha3S-Xyl [1]. Ulvan has been shown to possess various pharmacological properties, such as antioxidant [2], anticoagulant [3], antitumor [4], antihyperlipidemic [5], and antiviral [6] activities. However, its biological activity is greatly affected by its molecular weight, and its application could be limited by its high viscosity $[3,7,8]$. Compared to high-molecular-weight ulvan, low-molecular-weight ulvan possesses higher solubility, lower viscosity, easier absorption, and greater exposure of reactive groups $[3,5,9]$. In addition, it has been reported that low-molecular-weight sulfated polysaccharides [7] and their iron complexes [10] have potent biological activity. Thus, ulvan-derived oligosaccharides have been attracting increased attention for their tremendous potential for applications in the functional food and pharmaceutical industries.

Several methods for depolymerizing polysaccharides have been studied. Qi et al. prepared different molecular weight ulvans by treatment with $\mathrm{H}_{2} \mathrm{O}_{2}$ and by changing the depolymerization conditions [7]. Yu et al. degraded ulvan by microwaving under different pressures [8]. Mild acid hydrolysis has also been used to degrade ulvan [1]. However, such chemical and physical methods 
have many shortcomings, including sulfate group loss, complex products, and low oligosaccharide yields [9]. In contrast, enzymatic depolymerization is a potentially energy-efficient and environmentally friendly method, with no requirement for harsh reagents or extreme conditions [11]. Moreover, specific enzymes can be very useful for studying polysaccharide structure [12,13]. Therefore, it is necessary to find new enzymes that are capable of degrading ulvan, such as ulvan lyases.

The first marine bacterium capable of degrading ulvan was isolated by Lahaye et al. [12]. However, no in-depth study of its ulvan-degrading enzymes has been reported. Recently, Collén et al. reported the first endolytic ulvan lyase genes [14], which were found in the ulvanolytic bacterium Nonlabens ulvanivorans. Subsequently, the genomes of three ulvanolytic bacteria were sequenced [15], and ulvan lyases belonging to different polysaccharide lyase families were found. Kopel et al. reported several ulvan lyases in these three genomes [15], and these ulvan lyases showed no homology to those found by Collén et al. [14], which belong to PL24 family. Foran et al. identified another novel ulvan lyase (LOR_29) in the Alteromonas sp. LOR genome, which is the founding member of polysaccharide lyase family 25 (PL25) [16]. Thus far, three ulvan lyase families have been established (http://www.cazy.org), including PL24, PL25, and PL28. Structural characterizations of representative enzymes from these three families have also been reported [17-19]. As the primary ulvan-degrading enzyme [16], ulvan lyase catalyzes $\beta$-elimination at the internal bond between uronic acid and Rha3S, producing oligosaccharides with unsaturated uronic acid $(\Delta \mathrm{GlcA})[14,15]$. Compared to other methods, the uniform enzymatic product is an advantage of using ulvan lyases to degrade ulvan, which is convenient for studying their pharmacological activity. In addition, sulfate groups are well retained during the degradation process, which is essential for the activity of ulvan oligosaccharides [9]. Ulvan lyases have also been used for epitope deletion studies [20]. However, only seven ulvan lyases have been characterized. To expand the repertoire of enzymes to efficiently produce ulvan-derived oligosaccharides, additional new ulvan lyases must be investigated.

Previous studies showed that Alteromonas sp. A321 was capable of degrading ulvan [9]. In this study, a new ulvan lyase gene, ALT3695, was identified in Alteromonas sp. A321 and soluble expression of ALT3695 was achieved in Escherichia coli BL21 (DE3). Recombinant ulvan lyases were purified and the molecular weight was investigated. ALT3695 differs from other enzymes previously found in Alteromonas sp. A321 [21]. Thus, this study reports a new enzyme for preparing ulvan-derived oligosaccharides and enriches the marine enzyme library.

\section{Results and Discussion}

\subsection{Sequence Analysis}

The ALT3695 gene is $1314 \mathrm{bp}$ in length and encodes a 437-amino acid protein. The ALT3695 amino acid sequence shares $64.14 \%, 62.68 \%$, and $57.37 \%$ sequence identity with reported ulvan lyases from Pseudoalteromonas sp. PLSV (PLSV_3936, GenBank accession no. WP_033186995.1) [18], Alteromonas sp. LOR (LOR_29, GenBank accession no. WP_052010178.1) [16], and Nonlabens ulvanivorans PLR (NLR_492, GenBank accession no. WP_036580476.1) [16], respectively. As the representative enzyme of PL25 family, the structure and catalytic mechanism of PLSV_3936 have been investigated [18]. In PLSV_3936, His123, His143, Tyr 188, Arg204, and Tyr246 are conserved and have been proposed as active site residues, and Gln66, Tyr246, and Arg282 are highly conserved.

Several homologous enzymes from different organisms with less sequence identity were selected in the carbohydrate-active enzymes (CAZy) database. Amino acid sequence alignment showed that most residues are also conserved in ALT3695 and other PL25 family members, except Gln66 (Figure 1). Among these residues, His143 and Try246 could help Arg204 to neutralize the negative charge on glucuronic acid. His123 and Tyr188 were acid-base catalysis residues [18]. A phylogenetic tree of ALT3695 and other reported ulvan lyases was constructed by the neighbor-joining method, which suggested that ALT3695 is a PL25 family ulvan lyase (Figure 2). 

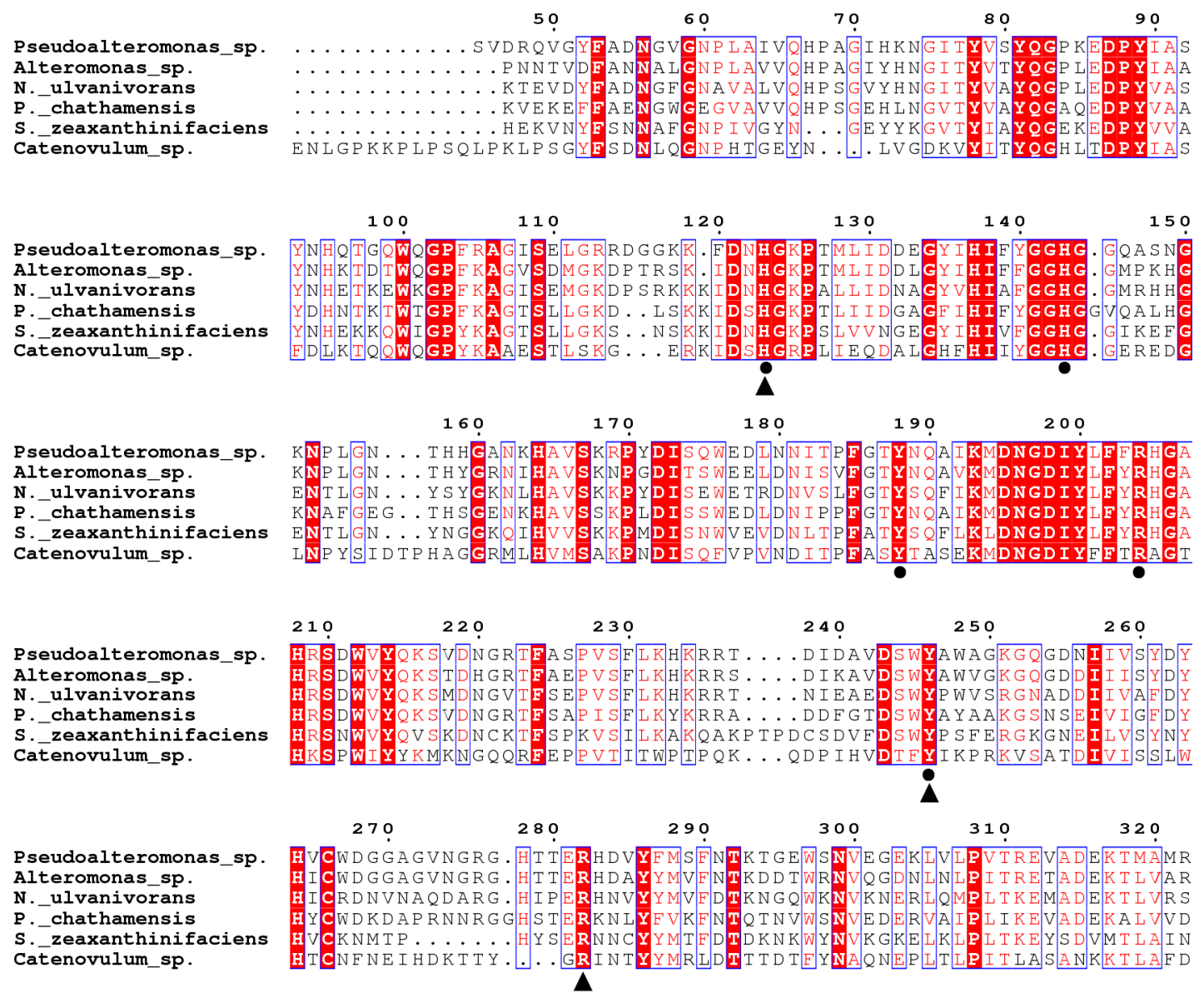

Figure 1. Amino acid sequence alignment of ALT3695 with ulvan lyases from Pseudoalteromonas sp. PLSV (PLSV_3936, GenBank accession no. WP_033186995.1), Alteromonas sp. A321 (ALT3695, GenBank accession no. MN347032), Nonlabens ulvanivorans PLR (NLR_492, GenBank accession no. WP_036580476.1), Paraglaciecola chathamensis S18K6 (GCHA_4617, GenBank accession no. GAC12534.1), Siansivirga zeaxanthinifaciens CC-SAMT-1 (AW14_13480, GenBank accession no. AJR04515.1), and Catenovulum sp. CCB-QB4 (C2869_03520, GenBank accession no. AWB65560.1). Active site residues are marked with filled circles $(\bullet)$. Highly conserved residues are marked with filled triangles $(\mathbf{\Lambda})$.

\subsection{Expression and Purification of Recombinant ALT3695}

Soluble expression of His-tagged ALT3695 ulvan lyase was achieved in E. coli BL21 (DE3) by adding $1 \mathrm{mM}$ isopropyl $-\beta$-d-thiogalactopyranoside (IPTG). The recombinant ALT3695 was purified, and SDS-PAGE showed only a single protein band. The purified ALT3695 showed a specific activity of $1.88 \mathrm{U} / \mathrm{mg}$ protein, with $52 \%$ recovery (Table 1 ). As expected, the apparent molecular weight was $53 \mathrm{kDa}$ (Figure 3), which is similar to that previously reported for PL25 family ulvan lyases, such as LOR_29 (52 kDa) [16] and NLR_492 (55 kDa) [16]. The molecular weight of ulvan lyases from other families, such as IL45_01510 (GenBank accession no. AEN28574.1, PL28) [14] and PsPL (GenBank accession no. AMA19992.1, PL24) [22], were about $46 \mathrm{kDa}$ and $59 \mathrm{kDa}$, respectively. 


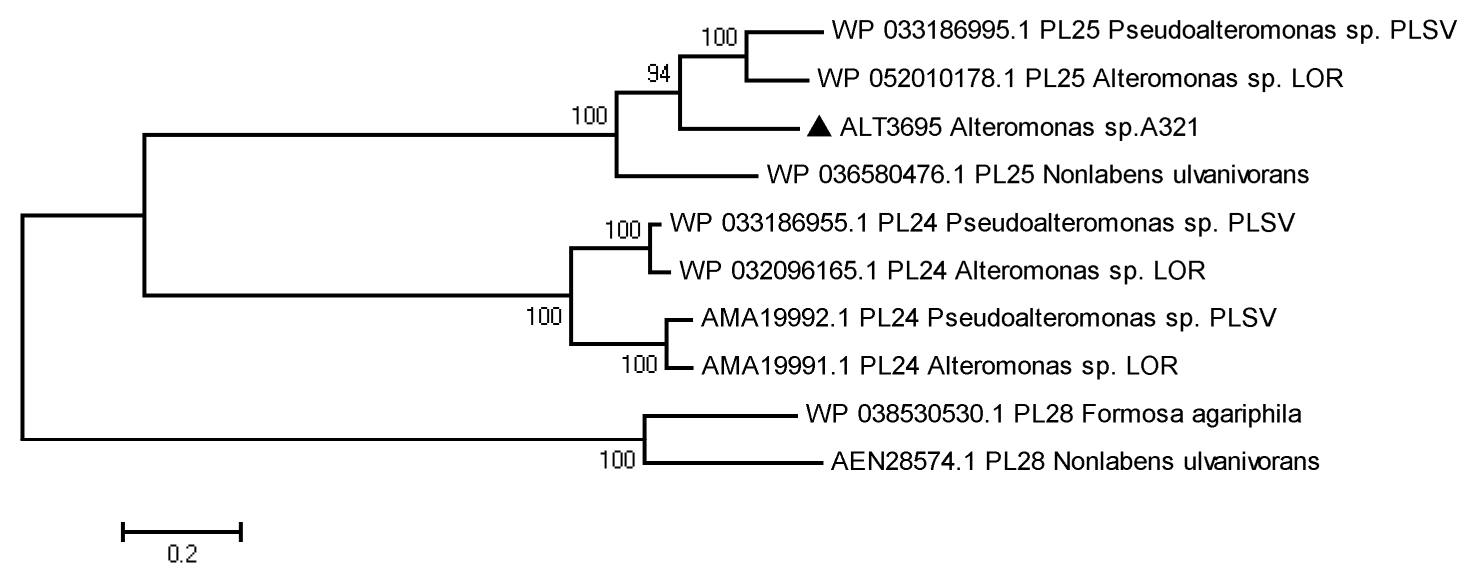

Figure 2. Phylogenetic tree of ALT3695 (filled triangle) and other ulvan lyases generated using the neighbor-joining method. Numbers along the branch nodes represent bootstrap percentages based on 1000 resamplings. The scale bar indicates the average number (0.2) of amino acid substitutions per site. Pseudoalteromonas sp. PLSV (PLSV_3936, GenBank accession no. WP_033186995.1), Alteromonas sp. LOR (LOR_29, GenBank accession no. WP_052010178.1), Nonlabens ulvanivorans (NLR_492, GenBank accession no. WP_036580476.1), Pseudoalteromonas sp. PLSV (PLSV_3925, GenBank accession no. WP_033186955.1), Alteromonas sp. LOR (LOR_107, GenBank accession no. AMA19991.1), Pseudoalteromonas sp. PLSV (PLSV_3875, GenBank accession no. AMA19992.1), Alteromonas sp. LOR (LOR_61, GenBank accession no. WP_032096165.1), Formosa agariphila KMM 3901 (BN863_22190, GenBank accession no. WP_038530530.1), and Nonlabens ulvanivorans PLR (IL45_01510, GenBank accession no. AEN28574.1).

Table 1. Characterization of purified ALT3695.

\begin{tabular}{cccccc}
\hline Purification Steps & $\begin{array}{c}\text { Total Protein } \\
(\mathbf{m g})\end{array}$ & $\begin{array}{c}\text { Total Activity } \\
\text { (U) }\end{array}$ & $\begin{array}{c}\text { Specific Activity } \\
\text { (U/mg) }\end{array}$ & $\begin{array}{c}\text { Purification } \\
\text { (fold) }\end{array}$ & $\begin{array}{c}\text { Yield } \\
\text { (\%) }\end{array}$ \\
\hline Crude enzymes & 21.39 & 20.49 & 0.96 & 1.00 & 100.00 \\
BeaverBeads $^{\mathrm{TM}}$ IDA-Nickel & 5.69 & 10.68 & 1.88 & 1.96 & 52.12 \\
\hline
\end{tabular}

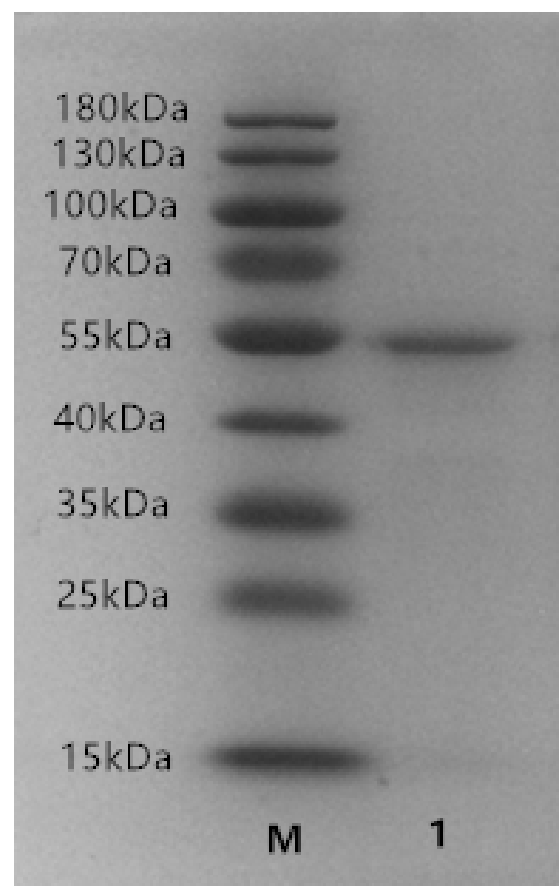

Figure 3. SDS-PAGE of purified ALT3695. Lane 1: purified ALT3695; Lane M: molecular weight marker. 


\subsection{Influence of Temperature on the Activity of Recombinant ALT3695}

The influence of temperature on enzyme stability and the optimum temperature for ALT3695 activity were investigated. Ulvan lyases from different families exhibit different optimum temperatures. The optimum temperature for ALT3695 activity was $50{ }^{\circ} \mathrm{C}$ (Figure 4a), which is higher than that of another ulvan lyase from the PL25 family $\left(45^{\circ} \mathrm{C}\right)$ [16]. Ulvan lyases from other families, such as FaPL28 (GenBank accession no. WP_038530530.1, PL28) [23] and PsPL (GenBank accession no. AMA19992.1, PL24) [22], showed maximum activity at lower temperatures of $29.5^{\circ} \mathrm{C}$ and $35^{\circ} \mathrm{C}$, respectively. Little has been reported concerning the thermal stability of PL25 family members. FaPL28 had poor thermal stability, and less than $10 \%$ activity was observed after incubation for $3 \mathrm{~h}$ at or above $30.9{ }^{\circ} \mathrm{C}$ [23]. In contrast, ALT3695 was relatively thermostable and $90 \%$ activity was observed even after incubation for $3 \mathrm{~h}$ at $40{ }^{\circ} \mathrm{C}$ (Figure $4 \mathrm{~b}$ ). However, the stability of ALT3695 decreased as the temperature was increased above $40{ }^{\circ} \mathrm{C}$ (Figure $4 \mathrm{~b}$ ), $49 \%$ residual activity was observed after incubation for $3 \mathrm{~h}$ at $45^{\circ} \mathrm{C}$, and no activity was observed after incubation at $55^{\circ} \mathrm{C}$ for $1 \mathrm{~h}$.
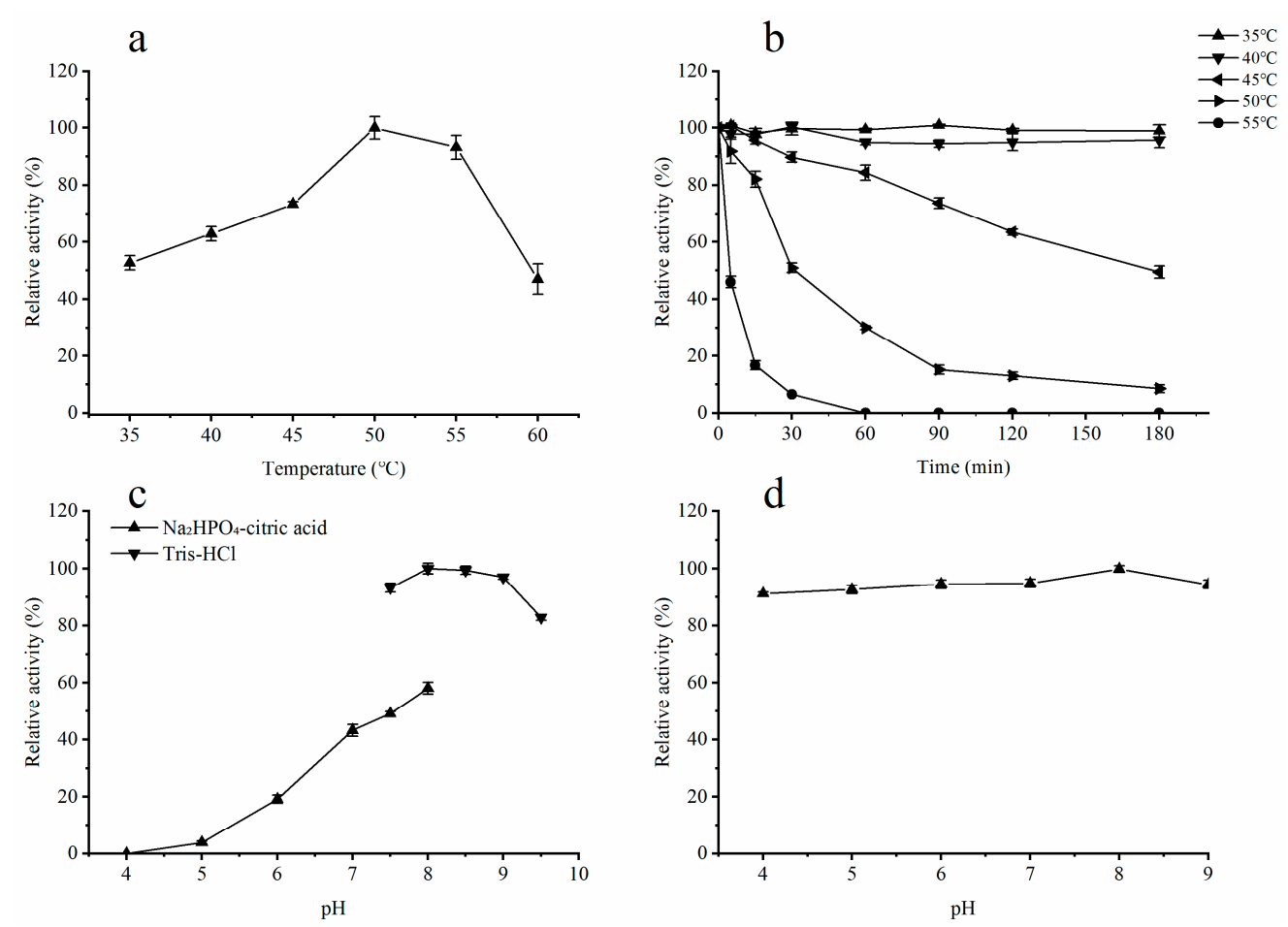

Figure 4. Biochemical characterization of ALT3695. (a) Activity of ALT3695 over a range of temperatures $\left(35-60{ }^{\circ} \mathrm{C}\right)$ to determine the optimal temperature. (b) Thermal stability of ALT3695. (c) Activity of ALT3695 over a range of $\mathrm{pH}$ values to determine the optimal $\mathrm{pH}$. (d) The $\mathrm{pH}$ stability of ALT3695.

\subsection{Influence of $\mathrm{pH}$ on the Activity of Recombinant ALT3695}

To investigate the effect of $\mathrm{pH}$ on ALT3695 activity, different buffers ( $\mathrm{pH} 4-9.5)$ were used. The optimum $\mathrm{pH}$ of other ulvan lyases ranged from 7.5 to $9.0[16,22,23]$, which corresponds to the $\mathrm{pH}$ of slightly alkaline seawater [24]. Similarly, ALT3695 showed maximal activity at pH 8.0 (Figure 4c). In addition, activity in Tris- $\mathrm{HCl}$ buffer was higher than that in $\mathrm{Na}_{2} \mathrm{HPO}_{4}$-citric acid buffer at $\mathrm{pH} 8.0$, suggesting that the catalytic activity of ALT3695 was also affected by the buffer salt. ALT3695 retained $80 \%$ activity after pre-incubation at $\mathrm{pH} 4.0-9.0$ for $2 \mathrm{~h}$ at $4^{\circ} \mathrm{C}$, indicating that ALT3695 has excellent $\mathrm{pH}$ stability (Figure $4 \mathrm{~d}$ ).

\subsection{Influences of Surfactants, Metal Ions, and Metal Chelators on the Activity of Recombinant ALT3695}

Table 2a shows the influence of various metal ions on ALT3695 activity. $\mathrm{K}^{+}$had no significant influence on ALT3695 activity. Additionally, $\mathrm{Fe}^{2+}$ and $\mathrm{Cu}^{2+}$ decreased enzyme activity, and this effect 
was also found in the ulvan lyases, PsPL [22] and FaPL28 [23]. Furthermore, ulvan lyases from different families exhibit different responses to $\mathrm{Co}^{2+}$, the activity of PsPL was increased by $\mathrm{Co}^{2+}$ [22], while the activity of FaPL28 [23] and ALT3695 was decreased by $\mathrm{Co}^{2+}$. This may be attributed to structural differences among these enzyme families. Moreover, $\mathrm{Cd}^{2+}, \mathrm{Hg}^{2+}$, and $\mathrm{Fe}^{3+}$ deactivated ALT3695 completely, which may be caused by the binding of these ions to the $\mathrm{SH}, \mathrm{CO}$, and $\mathrm{NH}$ moieties of amino acids, resulting in structural changes and inactivation [21]. It is worth mentioning that although ALT3695 has $\mathrm{Zn}^{2+}$-containing ligands, $\mathrm{Zn}^{2+}$ strongly inhibited enzymatic activity. Thus, $\mathrm{Zn}^{2+}$ may play a dual role, as inherent $\mathrm{Zn}^{2+}$ is essential for maintaining enzyme structure, but exogenous $\mathrm{Zn}^{2+}$ may bind to other amino acid residues and inhibit activity [25].

Table 2. (a) Effects of various metal ions on the activity of ALT3695 ulvan lyase. (b) Effects of surfactants and metal chelators on enzyme activity.

\begin{tabular}{|c|c|c|c|c|}
\hline \multicolumn{5}{|c|}{ (a) } \\
\hline Metal Ions & $\begin{array}{c}\text { Concentration } \\
(\mathrm{mM})\end{array}$ & $\begin{array}{c}\text { Relative Activity } \\
(\%)\end{array}$ & $\begin{array}{c}\text { Concentration } \\
(\mathrm{mM})\end{array}$ & $\begin{array}{c}\text { Relative Activity } \\
(\%)\end{array}$ \\
\hline Control & - & $100.01 \pm 1.37$ & - & $100.01 \pm 1.37$ \\
\hline $\mathrm{K}^{+}$ & 10 & $101.85 \pm 1.66$ & 20 & $103.62 \pm 1.92$ \\
\hline $\mathrm{Ca}^{2+}$ & 10 & $112.34 \pm 0.48$ & 20 & $142.51 \pm 2.62$ \\
\hline $\mathrm{Mg}^{2+}$ & 10 & $106.13 \pm 0.42$ & 20 & $117.13 \pm 2.12$ \\
\hline $\mathrm{Zn}^{2+}$ & 10 & ND & 20 & ND \\
\hline $\mathrm{Ba}^{2+}$ & 10 & $105.49 \pm 2.03$ & 20 & $121.23 \pm 2.39$ \\
\hline $\mathrm{Cu}^{2+}$ & 10 & $17.05 \pm 0.68$ & 20 & ND \\
\hline $\mathrm{Fe}^{2+}$ & 10 & $19.65 \pm 2.85$ & 20 & ND \\
\hline $\mathrm{Co}^{2+}$ & 10 & $29.88 \pm 2.51$ & 20 & ND \\
\hline $\mathrm{Cd}^{2+}$ & 10 & ND & 20 & ND \\
\hline $\mathrm{Hg}^{2+}$ & 10 & ND & 20 & ND \\
\hline $\mathrm{Fe}^{3+}$ & 10 & ND & 20 & ND \\
\hline \multicolumn{5}{|c|}{ (b) } \\
\hline Reagents & $\begin{array}{c}\text { Concentration } \\
(\mathrm{mM})\end{array}$ & $\begin{array}{l}\text { Relative Activity } \\
(\%)\end{array}$ & $\begin{array}{c}\text { Concentration } \\
(\mathrm{mM})\end{array}$ & $\begin{array}{c}\text { Relative Activity } \\
(\%)\end{array}$ \\
\hline Control & - & $100 \pm 0.21$ & - & $100 \pm 0.21$ \\
\hline Tween-20 & 5 & $98.73 \pm 2.22$ & 10 & $84.17 \pm 1.52$ \\
\hline Tween-80 & 5 & $103.29 \pm 0.44$ & 10 & $101.14 \pm 1.67$ \\
\hline Triton X-100 & 5 & $104.01 \pm 0.32$ & 10 & $97.36 \pm 1.85$ \\
\hline EDTA & 5 & $32.11 \pm 1.23$ & 10 & ND \\
\hline 1,10-phenanthroline & 5 & $106.71 \pm 0.79$ & 10 & $117.08 \pm 1.71$ \\
\hline
\end{tabular}

ND: No activity was determined.

The enzyme activity was increased by $\mathrm{Ca}^{2+}, \mathrm{Mg}^{2+}$, and $\mathrm{Ba}^{2+}$. The addition of $\mathrm{Ca}^{2+}$ would not only increase the activity of PL25 ulvan lyase, but also stimulate the activity of PsPL [22] and FaPL28 [23]. With more $\mathrm{Ca}^{2+}$ added, the activity of ALT3695 was also increased. In addition, ALT3695 activity decreased by $68 \%$ after pre-incubation in $5 \mathrm{mM}$ ethylenediaminetetraacetic acid (EDTA), similar phenomenon was also found in PsPL and FaPL28, this may due to the removal of divalent cations bound to enzymes. Additionally, structure analysis suggested that divalent metal ions play a structural role in all three ulvan lyase families.

The effect of surfactants and metal chelators on ALT3695 activity was also investigated (Table 2b). It has been reported that non-ionic surfactants could increase the activity of some enzymes [26,27]. However, surfactants had little effect on the activity of ALT3695.

\subsection{Kinetic Parameters of Recombinant ALT3695}

$V_{\max }$ is the maximum initial rate of an enzymatic reaction. Each enzyme has a specific $K_{m}$ for each substrate, which is inversely related to the enzyme's affinity for the substrate [28]. The kinetic 
parameters of other ulvan lyases from the PL25 family have not yet been reported. The $K_{m}$ and $V_{\max }$ of recombinant ALT3695 toward ulvan were $0.43 \mathrm{mg} \cdot \mathrm{mL}^{-1}$ and $0.11 \mu \mathrm{mol} \cdot \mathrm{min}^{-1} \cdot \mathrm{mL}^{-1}$, respectively, as determined by the Lineweaver-Burk plot. ALT3695 showed a higher affinity for ulvan than PsPL and FaPL28, which had a $K_{m}$ of $2.10 \mathrm{mg} \cdot \mathrm{mL}^{-1}$ [22] and $0.75 \mathrm{mg} \cdot \mathrm{mL}^{-1}$ [23], respectively, suggesting the potential of ALT3695 for application.

\subsection{Analysis of Enzymatic Products}

The main repetitive disaccharide units in ulvan are Rha3S-GlcA, Rha3S-IduA, and Rha3S-Xyl. ALT3695 could cleave the bond on both Rha3S-GlcA and Rha3S-IdoA, while PL24 family ulvan lyase specifically cleaves the bond between Rha3S-GlcA. The products of ulvan degradation by ALT3695 were analyzed by negative electrospray ionisation mass spectrometry (ESI-MS). Mass spectroscopic analysis of products showed two major types of oligosaccharides. The peak at $\mathrm{m} / \mathrm{z} 401$ was equivalent to the disaccharide $\Delta$ GlcA-Rha3S, with a molecular weight of $402 \mathrm{Da}$. There was an unsaturated double bond between $\mathrm{C} 4$ and $\mathrm{C} 5$ [18]. The peak at $\mathrm{m} / \mathrm{z} 379$ was equivalent to double-charged molecular ions of the tetrasaccharide $\Delta$ GlcA-Rha3S-Xyl-Rha3S, with a molecular weight of $760 \mathrm{Da}$ [14]. A low abundance of single-charged molecular ions of this tetrasaccharide was also identified as the peak at $\mathrm{m} / \mathrm{z} 759$. However, the products of ulvan degradation by PL24 ulvan lyase were different. The products included the two most abundant oligosaccharides which comprised of disaccharides ( $\triangle$ GlcA-Rha3S) and tetrasaccharides ( $\Delta$ GlcA-Rha3S-IdoA-Rha3S), with minor tetrasaccharides ( $\Delta$ GlcA-Rha3S-Xyl-Rha3S) [15].

Moreover, the change in the full wavelength during enzymatic degradation was studied (Figure $5 b$ ). As the enzymatic reaction continued, the absorption peak at $235 \mathrm{~nm}$ gradually increased, which may be due to the generation of $\Delta$ GlcA-Rha3S and $\Delta$ GlcA-Rha3S-Xyl-Rha3S, as C-4=C-5 double bonds have a high absorbance at $235 \mathrm{~nm}$ [29].
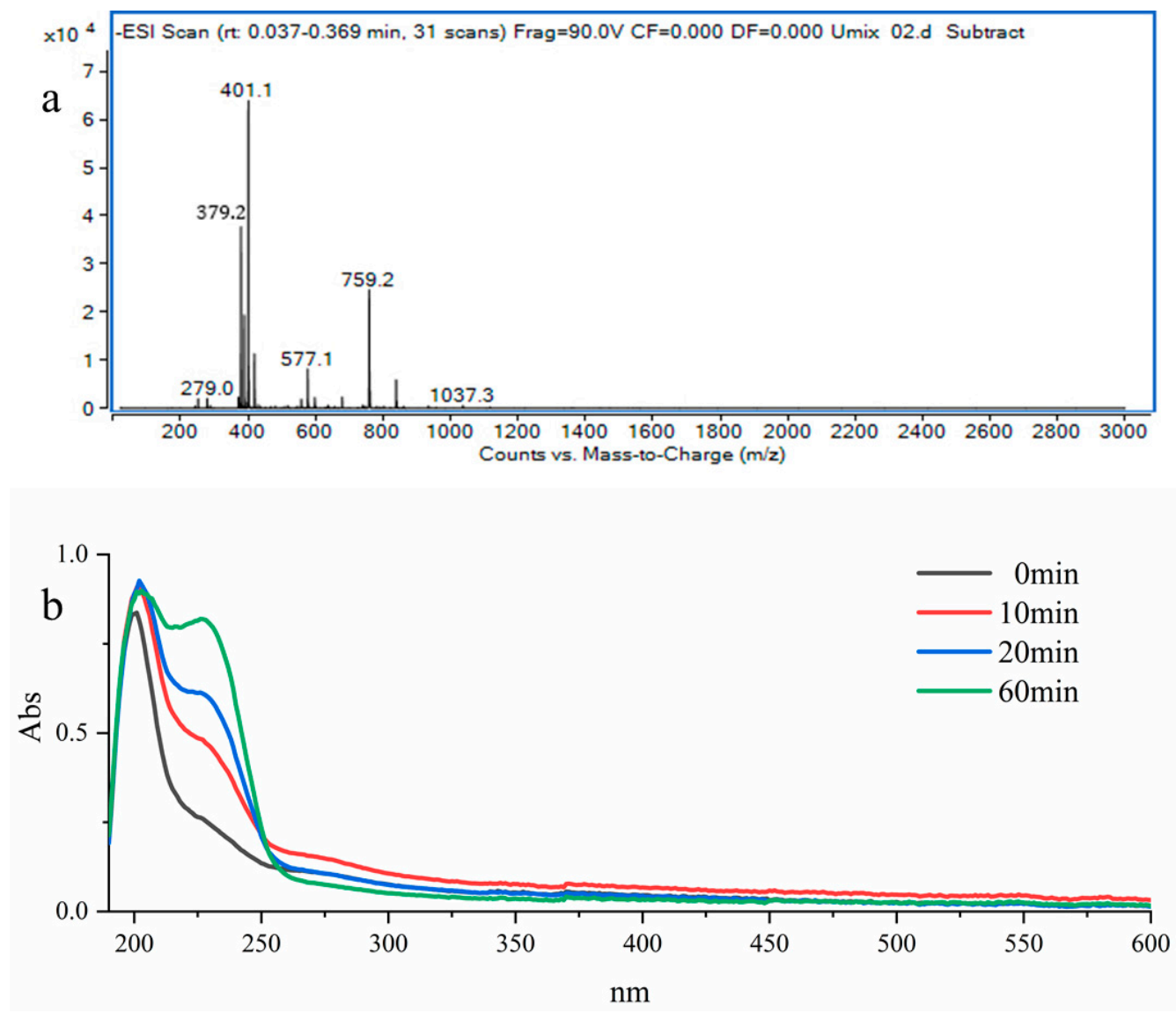

Figure 5. Analysis of the enzymatic products of ulvan generated by ALT3695. (a) ESI-MS analysis of products. (b) Full wavelength scans conducted during enzymatic degradation. 


\section{Materials and Methods}

\subsection{Strains, Plasmids, and Medium}

The ulvan-degrading strain Alteromonas sp. A321 was provided by Peng Wang (Ocean University of China, Qingdao, China). Genomic DNA was extracted, and the whole genome was sequenced. E. coli strains DH5 $\alpha$ and BL21 (DE3) were purchased from TIANGEN Biotech Co. (Beijing, China). The pProEX-HTa vector was used to clone and express the ulvan lyase gene. The E. coli strains were cultured in Luria-Bertani medium.

\subsection{Sequence Analysis}

An ulvan lyase gene, named ALT3695, was identified in the genome, and its sequence was deposited into the NCBI database (GenBank accession no. MN347032). DNAMAN 9 (Lynnon Biosoft, San Ramon, CA, USA) software was used to analyze the sequence of ALT3695. The homology was analyzed using BLAST at the NCBI website. A phylogenetic tree based on the homology of various ulvan lyases was constructed using MEGA 5.0 (Koichiro, Tokyo, Japan).

\subsection{Construction of the Recombinant ALT3695-Expressing Strain}

The ALT3695 gene was amplified by PCR using Phanta ${ }^{\circledR}$ Turbo Super-Fidelity DNA Polymerase (Vazyme Biotech, Nanjing, China). Two primers were designed to amplify the ALT3695 gene, 5'-CCGGAATTCCGGCCCAATAATACTGTCGACTTCGCTAACA-3' and 5'-GGGGTACCCCTTACTTATTCTCGCTTCGTATTGGTCC-3'. Then, the amplicon was purified, digested, and ligated into the pProEX-HTa vector to generate pProEX-HTa-ALT3695. The recombinant plasmid pProEX-HTa-ALT3695 was transformed into E. coli DH5 $\alpha$ for amplification, and then transformed into E. coli BL21(DE3) for expression. Positive strains were verified by sequencing.

\subsection{Expression of Recombinant ALT3695}

E. coli BL21 (DE3) cells containing pProEX-HTa-ALT3695 were cultivated in Luria-Bertani medium supplemented with ampicillin $(100 \mu \mathrm{g} / \mathrm{mL})$. The culture conditions were $37^{\circ} \mathrm{C}$ and $200 \mathrm{rpm}$. When the strain entered logarithmic growth phase (OD600 0.7), IPTG was added at a final concentration of $1 \mathrm{mM}$ to induce the expression of ALT3695. Then, the culture temperature was decreased to $28^{\circ} \mathrm{C}$, but $200 \mathrm{rpm}$ was retained with further cultivation for $18 \mathrm{~h}$. Finally, cells were collected by centrifugation under freezing conditions $\left(4^{\circ} \mathrm{C}\right)$ and resuspended in $20 \mathrm{mM}$ Tris- $\mathrm{HCl}$ buffer (pH 7.5).

\subsection{Enzyme Purification}

After homogenization by sonication, the supernatant containing crude enzymes was obtained by centrifugation under freezing conditions. The His-tagged ulvan lyase was purified using BeaverBeads ${ }^{\mathrm{TM}}$ IDA-Nickel (Beaverbio, Suzhou, China) and eluted using $20 \mathrm{mM}$ Tris-HCl buffer (pH 7.5) supplemented with $0.5 \mathrm{M} \mathrm{NaCl}$ and $300 \mathrm{mM}$ imidazole. The concentration of soluble protein was determined by the Folin-Ciocalteu method [30]. Purified enzyme was then subjected to SDS-PAGE to analyze the purity and molecular mass [31].

\subsection{Enzyme Activity Assay}

Ulvan was extracted from Ulva clathrate (Fujian, China) according to the method of Qi et al. [32]. The ulvan substrate was added at $0.1 \%(\mathrm{w} / \mathrm{v})$ in $50 \mathrm{mM}$ Tris- $\mathrm{HCl}$ buffer $(\mathrm{pH} 8.0)$ and the reaction was conducted at $35^{\circ} \mathrm{C}$. The activity of ulvan lyase was examined by measuring the change in absorbance at $235 \mathrm{~nm}$ [14]. One unit (U) of ulvan lyase activity was defined as the amount of protein needed to generate $1 \mu \mathrm{mol}$ of unsaturated glucuronyl residue (extinction coefficient, $4800 \mathrm{M}^{-1} \cdot \mathrm{cm}^{-1}$ ) per minute [23]. All assays were repeated three times. 


\subsection{Characterization of Recombinant ALT3695}

To examine the optimum temperature of recombinant ALT3695, the reaction was conducted at $35-60{ }^{\circ} \mathrm{C}$ under standard conditions. The change in enzyme stability at different temperatures was analyzed by conducting enzyme activity assays after pre-incubating the enzyme for various times ( 5 , $15,30,60,90,120$, and $180 \mathrm{~min})$ at $35-60{ }^{\circ} \mathrm{C}$.

The optimal $\mathrm{pH}$ of recombinant ALT3695 was investigated by examining its activity in $50 \mathrm{mM}$ $\mathrm{Na}_{2} \mathrm{HPO}_{4}$-citric acid buffer (for $\mathrm{pH} 4.0-8.0$ ) and $50 \mathrm{mM}$ Tris- $\mathrm{HCl}$ buffer (for $\mathrm{pH}$ 7.5-9.5). To investigate the change of enzyme stability by $\mathrm{pH}$, purified enzymes were stored for $2 \mathrm{~h}$ at $4{ }^{\circ} \mathrm{C}$ in buffers of different $\mathrm{pH}$ levels, and then assayed for residual enzyme activity.

To examine the influence of different metal ions on recombinant ALT3695 activity, the enzyme was incubated with various metal ions (at $10 \mathrm{mM}$ and $20 \mathrm{mM}$ ) for $2 \mathrm{~h}$ at $4{ }^{\circ} \mathrm{C}$. The following metal ions were tested: $\mathrm{K}^{+}, \mathrm{Ca}^{2+}, \mathrm{Mg}^{2+}, \mathrm{Zn}^{2+}, \mathrm{Ba}^{2+}, \mathrm{Cu}^{2+}, \mathrm{Fe}^{2+}, \mathrm{Hg}^{2+}, \mathrm{Co}^{2+}, \mathrm{Cd}^{2+}$, and $\mathrm{Fe}^{3+}$. The effect of the following surfactants and metal chelators on recombinant ALT3695 activity was also determined: Tween-20, Tween-80, Triton X-100, EDTA, and 1,10-phenanthroline. The enzyme solution was stored with each surfactant or potential inhibitor (at $5 \mathrm{mM}$ and $10 \mathrm{mM}$ ) for $2 \mathrm{~h}$ at $4{ }^{\circ} \mathrm{C}$. Then, enzyme activity was assayed and compared with the activity in the absence of additive.

\subsection{Kinetic Measurements}

To determine the kinetic parameters of recombinant ALT3695 using ulvan as a substrate, reactions were performed with various concentrations $\left(0.03125-1.0 \mathrm{mg} \cdot \mathrm{mL}^{-1}\right)$ of substrate under standard conditions for $5 \mathrm{~min}$. Then, the $K_{m}$ and $V_{\max }$ values were calculated by constructing a Lineweaver-Burk double reciprocal plot.

\subsection{Analysis of Enzymatic Products}

To obtain enzymatic products for analysis, purified ALT3695 was incubated with ulvan $\left(5 \mathrm{mg} \cdot \mathrm{mL}^{-1}\right)$ for $3 \mathrm{~h}$ at $35^{\circ} \mathrm{C}$. Then, product samples were collected, and the product molecular weights were measured by negative-ion ESI-MS (Agilent 1290 Infinity II-6460, Agilent Corp., Wilmington, DE, USA; Frag $=90.0 \mathrm{~V}, \mathrm{~m} / \mathrm{z}$ 100-3000 amu). Full wavelength scans $(190-600 \mathrm{~nm})$ were obtained during enzymatic degradation.

\section{Conclusions}

ALT3695 is a new ulvan lyase identified from Alteromonas sp. A321. The gene was cloned, and the recombinant ALT3695 was expressed in soluble fraction. The enzymatic properties were also investigated. The enzyme exhibited excellent stability and substrate affinity. Maximum activity was observed at $50{ }^{\circ} \mathrm{C}$, and $90 \%$ activity remained after incubation at $40{ }^{\circ} \mathrm{C}$ for $3 \mathrm{~h}$. ALT3695 catalyzes $\beta$-elimination at the internal bonds between uronic acids and Rha3S, leading to increased absorbance at $235 \mathrm{~nm}$. ESI-MS results showed that disaccharides and tetrasaccharides were the major enzymatic products. In conclusion, ALT3695 shows great potential for the preparation of ulvan oligosaccharides. Further research on this recombinant strain and a structural analysis of ulvan lyase ALT3695 are warranted based on results of this study.

Author Contributions: J.G., C.D., and P.W. conceived and designed the experiments; J.G., C.D., and Y.C. performed the experiments; S.Z. and H.Y. analyzed the data; J.G. and P.W. wrote the paper.

Funding: This research was funded by the Key Research and Development Program of Shandong 2018GHY115032, the National Key Research and Development Program 2018YFC0311203 and the Innovation and Development of Marine Economy Demonstration City (Weihai) Program.

Conflicts of Interest: The authors declare no conflict of interest. 


\section{References}

1. Lahaye, M.; Robic, A. Structure and functional properties of ulvan, a polysaccharide from green seaweeds. Biomacromolecules 2007, 8, 1765-1774. [CrossRef] [PubMed]

2. Li, W.; Wang, K.; Jiang, N.; Liu, X.; Wan, M.; Chang, X.; Liu, D.; Qi, H.; Liu, S. Antioxidant and antihyperlipidemic activities of purified polysaccharides from Ulva pertusa. J. Appl. Phycol. 2018, 30, 2619-2627. [CrossRef]

3. Cui, J.; Li, Y.; Wang, S.; Chi, Y.; Hwang, H.; Wang, P. Directional preparation of anticoagulant-active sulfated polysaccharides from Enteromorpha prolifera using artificial neural networks. Sci. Rep. 2018, 8, 3062. [CrossRef]

4. Thanh, T.T.; Quach, T.M.; Nguyen, T.N.; Vu Luong, D.; Bui, M.L.; Tran, T.T. Structure and cytotoxic activity of ulvan extracted from green seaweed Ulva lactuca. Int. J. Biol. Macromol. 2016, 93, 695-702. [CrossRef] [PubMed]

5. Qi, H.; Huang, L.; Liu, X.; Liu, D.; Zhang, Q.; Liu, S. Antihyperlipidemic activity of high sulfate content derivative of polysaccharide extracted from Ulva pertusa (Chlorophyta). Carbohydr. Polym. 2012, 87, 1637-1640. [CrossRef]

6. Aguilar-Briseño, J.A.; Cruz-Suarez, L.E.; Sassi, J.F.; Ricque-Marie, D.; Zapata-Benavides, P.; Mendoza-Gamboa, E.; Rodríguez-Padilla, C.; Trejo-Avila, L.M. Sulphated polysaccharides from Ulva clathrata and Cladosiphon okamuranus seaweeds both inhibit viral attachment/entry and cell-cell fusion, in NDV infection. Mar. Drugs 2015, 13, 697-712. [CrossRef]

7. Qi, H.; Zhao, T.; Zhang, Q.; Li, Z.; Zhao, Z.; Xing, R. Antioxidant activity of different molecular weight sulfated polysaccharides from Ulva pertusa Kjellm (Chlorophyta). J. Appl. Phycol. 2005, 17, 527-534. [CrossRef]

8. Yu, P.; Li, N.; Liu, X.; Zhou, G.; Zhang, Q.; Li, P. Antihyperlipidemic effects of different molecular weight sulfated polysaccharides from Ulva pertusa (Chlorophyta). Pharmacol. Res. 2003, 48, 543-549.

9. Li, Y.; Wang, J.; Yu, Y.; Li, X.; Jiang, X.; Hwang, H.; Wang, P. Production of enzymes by Alteromonas sp. A321 to degrade polysaccharides from Enteromorpha prolifera. Carbohydr. Polym. 2013, 98, 988-994. [CrossRef]

10. Cui, J.; Li, Y.; Yu, P.; Zhan, Q.; Wang, J.; Chi, Y.; Wang, P. A novel low molecular weight Enteromorpha polysaccharide-iron (III) complex and its effect on rats with iron deficiency anemia (IDA). Int. J. Biol. Macromol. 2018, 108, 412-418. [CrossRef]

11. Li, Y.; Huang, Z.; Qiao, L.; Gao, Y.; Guan, H.; Hwang, H.; Aker, W.G.; Wang, P. Purification and characterization of a novel enzyme produced by Catenovulum sp. LP and its application in the pre-treatment to Ulva prolifera for bio-ethanol production. Process Biochem. 2015, 50, 799-806. [CrossRef]

12. Lahaye, M.; Brunel, M.; Bonnin, E. Fine chemical structure analysis of oligosaccharides produced by an ulvan-lyase degradation of the water-soluble cell-wall polysaccharides from Ulva sp. (Ulvales, Chlorophyta). Carbohydr. Res. 1997, 304, 325-333. [CrossRef]

13. Konasani, V.R.; Jin, C.; Karlsson, N.G.; Albers, E. Ulvan lyase from Formosa agariphila and its applicability in depolymerisation of ulvan extracted from three different Ulva species. Algal Res. 2018, 36, 106-114. [CrossRef]

14. Collén, P.N.; Sassi, J.F.; Rogniaux, H.; Marfaing, H.; Helbert, W. Ulvan lyases isolated from the Flavobacteria Persicivirga ulvanivorans are the first members of a new polysaccharide lyase family. J. Biol. Chem. 2011, 286, 42063-42071. [CrossRef] [PubMed]

15. Kopel, M.; Helbert, W.; Belnik, Y.; Buravenkov, V.; Herman, A.; Banin, E. New family of ulvan lyases identified in three isolates from the alteromonadales order. J. Biol. Chem. 2016, 291, 5871-5878. [CrossRef] [PubMed]

16. Foran, E.; Buravenkov, V.; Kopel, M.; Mizrahi, N.; Shoshani, S.; Helbert, W.; Banin, E. Functional characterization of a novel "ulvan utilization loci" found in Alteromonas sp. LOR genome. Algal Res. 2017, 25, 39-46. [CrossRef]

17. Ulaganathan, T.; Helbert, W.; Kopel, M.; Banin, E.; Cygler, M. Structure-function analyses of a PL24 family ulvan lyase reveal key features and suggest its catalytic mechanism. J. Biol. Chem. 2018, 293, 4026-4036. [CrossRef]

18. Ulaganathan, T.; Boniecki, M.T.; Foran, E.; Buravenkov, V.; Mizrachi, N.; Banin, E.; Helbert, W.; Cygler, M. New ulvan-degrading polysaccharide lyase family: structure and catalytic mechanism suggests convergent evolution of active site architecture. ACS Chem. Biol. 2017, 12, 1269-1280. [CrossRef] 
19. Ulaganathan, T.; Banin, E.; Helbert, W.; Cygler, M. Structural and functional characterization of PL28 family ulvan lyase NLR48 from Nonlabens ulvanivorans. J. Biol. Chem. 2018, 293, 11564-11573. [CrossRef]

20. Rydahl, M.G.; Kračun, S.K.; Fangel, J.U.; Michel, G.; Guillouzo, A.; Génicot, S.; Mravec, J.; Harholt, J.; Wilkens, C.; Motawia, M.S.; et al. Development of novel monoclonal antibodies against starch and ulvan-implications for antibody production against polysaccharides with limited immunogenicity. Sci. Rep. 2017, 7, 9326. [CrossRef]

21. Li, Y.; Li, W.; Zhang, G.; Lü, X.; Hwang, H.; Aker, W.G.; Wang, P. Purification and characterization of polysaccharides degradases produced by Alteromonas sp. A321. Int. J. Biol. Macromol. 2016, 86, 96-104. [CrossRef]

22. Qin, H.M.; Xu, P.; Guo, Q.; Cheng, X.; Gao, D.; Sun, D.; Zhu, Z.; Lu, F. Biochemical characterization of a novel ulvan lyase from Pseudoalteromonas sp. strain PLSV. RSC Adv. 2018, 8, 2610-2615. [CrossRef]

23. Reisky, L.; Stanetty, C.; Mihovilovic, M.D.; Schweder, T.; Hehemann, J.H.; Bornscheuer, U.T. Biochemical characterization of an ulvan lyase from the marine flavobacterium Formosa agariphila KMM $3901^{\mathrm{T}}$. Appl. Microbiol. Biotechnol. 2018, 102, 6987-6996. [CrossRef] [PubMed]

24. Dickson, A.G. The measurement of sea water pH. Mar. Chem. 1993, 44, 131-142. [CrossRef]

25. Chen, L.; Feng, Y.; Zhou, Y.; Zhu, W.; Shen, X.; Chen, K.; Jiang, H.; Liu, D. Dual role of $\mathrm{Zn}^{2+}$ in maintaining structural integrity and suppressing deacetylase activity of SIRT1. J. Inorg. Biochem. 2010, 104, 180-185. [CrossRef]

26. Okino, S.; Ikeo, M.; Ueno, Y.; Taneda, D. Effects of Tween 80 on cellulase stability under agitated conditions. Bioresour. Technol. 2013, 142, 535-539. [CrossRef] [PubMed]

27. Yang, M.; Zhang, A.; Liu, B.; Li, W.; Xing, J. Improvement of cellulose conversion caused by the protection of Tween-80 on the adsorbed cellulase. Biochem. Eng. J. 2011, 56, 125-129. [CrossRef]

28. Xie, H.; Zhu, L.; Ma, T.; Wang, J.; Wang, J.; Su, J.; Shao, B. Immobilization of an enzyme from a Fusarium fungus WZ-I for chlorpyrifos degradation. J. Environ. Sci. 2010, 22, 1930-1935. [CrossRef]

29. Maruyama, Y.; Nakamichi, Y.; Itoh, T.; Mikami, B.; Hashimoto, W.; Murata, K. Substrate specificity of streptococcal unsaturated glucuronyl hydrolases for sulfated glycosaminoglycan. J. Biol. Chem. 2009, 284, 18059-18069. [CrossRef]

30. Lowry, O.H.; Rosebrough, N.J.; Farr, A.L.; Randall, R.J. Protein measurement with the Folin phenol reagent. J. Biol. Chem. 1951, 193, 265-275. [PubMed]

31. Laemmli, U.K. Cleavage of structural proteins during the assembly of the head of bacteriophage T4. Nature 1970, 227, 680-685. [CrossRef] [PubMed]

32. Qi, X.; Mao, W.; Gao, Y.; Chen, Y.; Chen, Y.; Zhao, C.; Li, N.; Wang, C.; Yan, M.; Lin, C.; et al. Chemical characteristic of an anticoagulant-active sulfated polysaccharide from Enteromorpha clathrate. Carbohydr. Polym. 2012, 90, 1804-1810. [CrossRef] [PubMed]

(C) 2019 by the authors. Licensee MDPI, Basel, Switzerland. This article is an open access article distributed under the terms and conditions of the Creative Commons Attribution (CC BY) license (http://creativecommons.org/licenses/by/4.0/). 